https://journal.uwgm.ac.id/index.php/abdimasmahakam

E-ISSN: 2549-5755

Januari 2020, Vol. 4 No. 01

Received: September 2019

Accepted: Desember 2019

Published: Januari 2020

Article DOI: http://dx.doi.org/ 10.24903/jam.v4i1.808

\title{
Pelatihan Pembuatan Tas Totte Sederhana bagi Kader Pkk Kelurahan Sungai Dama di Kota Samarinda
}

\author{
Nunung Herlina \\ Universitas Muhammadyah Kalimantan Timur \\ nh183@umkt.ac.id \\ Marjan Wahyuni \\ Universitas Muhammadyah Kalimantan Timur \\ mw894@umkt.ac.id \\ Faried Rahman Hidayat \\ Universitas Muhammadyah Kalimantan Timur \\ fariedrahmanhidayat@umkt.ac.id
}

\begin{abstract}
Abstrak
Dalam upaya meningkatkan ekonomi dalam keluarga, usaha peningkatan pendapatan keluarga dibutuhkan dimana usaha yang dimaksud adalah dengan cara memberdayakan pengetahuan dan keterampilan yang dimiliki oleh keluarga tersebut sehingga menjadi suatu bentuk kerajinan yang dipadukan dengan seni, yang menghasilkan benda yang bernilai jual. Untuk itu pelatihan keterampilan membuat tas totte ini penting dibuat sebagai wujud upaya peningkatan pendapatan keluarga. Tujuan: Pengabdian masyarakat ini adalah melatih Kader PKK untuk bisa terampil membuat Tas totte dan dapat menularkan ilmunya kepada warga sekitarnya. Metode Pengabdian: Pengadaan Pelatihan bertujuan untuk Meningkatkan Pengetahuan dan Keterampilan Kader PKK di Kelurahan Sungai Dama dalam membuat tas totte. Metode pelatihan dengan cara teori dan praktek langsung pembuatan pola tas dan menjahit tas. Jumlah kader PKK yang dilatih sejumlah 10 Kader, dengan empat kali pertemuan diharapkan menghasilkan satu buah karya yaitu tas totte sederhana dari bahan kain perca. Hasil pengabdian selama 4 hari, 10 kader PKK mampu membuat tas totte sederhana.
\end{abstract}

Kata Kunci: Pelatihan; Ketrampilan; Kader PKK; tas totte.

\section{Pendahuluan}

Didalam perkembangan masyarakat saat ini, terjadi penurunan ekonomi secara drastis, hargaharga melonjak naik dan kebutuhan keluarga menjadi meningkat. Sulitnya lapangan kerja dan kesulitan hidup merupakan gambaran kehidupan sehari hari terutama yang berasal dari kalangan ekonomi lemah. Upaya yang dapat dilakukan adalah bagaimana cara untuk dapat meningkatkan ekonomi keluarga. Dalam hal ini dibutuhkan inovasi-inovasi baru, dalam rangka mewujudkan peningkatan ekonomi dan pendapatan keluarga, melalui usaha 
pengembangan keterampilan sehingga diharapkan keluarga atau masyarakat menjadi titik tolak dalam usaha peningkatan kesejahteraan dalam keluarga.

Usaha peningkatan pendapatan keluarga adalah kegiatan usaha yang dilaksanakan oleh keluarga untuk meningkatkan pendapatan dalam rangka meningkatkan kesejahteraan keluarga. Dapat juga dijabarkan, usaha peningkatan adalah segala kegiatan ekonomi yang diusahakan oleh keluarga baik secara perorangan maupun kelompok yang modal usaha tersebut bisa berasal dari keluarga, swadaya masyarakat, bantuan pemerintah atau swasta serta sumber lainnya.

Usaha ekonomi adalah merupakan suatu strategi alternative pemberdayaan atau empowering keluarga untuk meningkatkan pendapatan keluarga. Hal ini dapat dilakukan dengan pendekatan yang bersifat social kemasyarakatan, yang bukan hanya meningkatkan pendapatan keluarga tetapi juga mencakup pengembangan kemampuan pengetahuan dan keterampilan warga masyarakat, kader dan anggota keluarga, sehingga mereka dapat mengkontribusi pemenuhan kebutuhan dalam keluarga.

Kader Pemberdayaan dan Kesejahteraan Keluarga adalah merupakan anggota masyarakat yang mampu menggerakkan partisipasi masyarakat, menggerakkan kegiatan dan melakukan upaya-upaya peningkatan serta pengembangan pengetahuan serta keterampilan keluarga. Para Kader ini perlu diberikan pengetahuan dan keterampilan khusus agar kemudian dengan kemampuan tersebut dapat menggerakkan orang-orang atau masyarakat sekitar mereka agar mempunyai kemampuan yang sama, sehingga tercapainya masyarakat yang mandiri, mampu dan mumpuni dalam upaya peningkatan ekonomi keluarga.

Sebagai salah satu penjabaran Tridharma perguruan tinggi adalah pengabdian masyarakat yang akan melaksanakan pendampingan kepada keluarga dan masyarakat. Pendampingan yang dimaksud adalah bagaimana secara bersama sama dengan masyarakat, menghadapi masalah dan tantangan, memecahkan masalahnya secara bersama-sama, merancang program perencanaan, melihat dan mengangkat potensi dan kekuatan yang ada dalam masyarakat tersebut

Dalam usaha peningkatan pendapatan keluarga dapat dirumuskan konsep mengenai upaya peningkatan pengetahuan dan keterampilan dalam membuat kerajinan tangan yang dapat dilakukan dirumah yang dalam hal ini sifatnya sederhana, biaya modalnya murah dan terjangkau, dapat menggunakan bahan - bahan limbah yaitu sisa kain perca yang dapat diolah menjadi tas disebut Simple totte bag. Adapun strategi kegiatan adalah dengan cara memberikan pelatihan secara langsung pada para kader Pemberdayaan dan Kesejahteraan Keluarga untuk pembuatan tas tersebut dan kemudian diharapkan, para kader ini akan menularkan pengetahuan dan keterampilannya kepada masyarakat sekitar, sehingga tujuan upaya peningkatan kesejahteraan masyarakat akan dapat tercapai.

\section{Metode}

Pada pertemuan pertama pelatihan, dijelaskan secara teori seperti pengertian Simple totte bag atau tas totte sederhana, macam-macam tas, ukuran, macam macam atau jenis kain dan contoh produk, selanjutnya diajarkan tentang bagaimana membuat pola. Dilanjutkan lagi dengan menjelaskan tentang cara menggunting kain, melapis dan bagaimana cara menjahit tas.

Praktek Membuat simple totte bag proses pembuatannya dilakukan secara berurutan, seperti mempersiapkan alat, membuat pola, menggunting kain dan kain pengeras sesuai pola, 


\section{(A) ABDIMAS}

https://journal.uwgm.ac.id/index.php/abdimasmahakam

E-ISSN: 2549-5755

Januari 2020, Vol. 4 No. 01

membuat tali atau jika menggunakan tali yang sudah jadi, membuat kantong, membentuk tas dilanjutkan memasang restluiting atau kancing magnet dan memasang puring.

\section{Hasil dan Pembahasan}

Kegiatan dilaksanakan mulai dari persiapan, menghubungi Lurah di Kelurahan Sungai Dama, melalui Kepala Seksi Pemberdayaan memberikan surat ijin untuk pelaksanaan Pengabdian Masyarakat. Dilanjutkan dengan pendataan kader, terpilih sebanyak 10 orang kader Tim Penggerak Pemberdayaan dan Kesejahteraan Keluarga Kelurahan Sungai Dama yang punya potensi dalam mengembangkan program ini kedepannya. Setelah surat ijin dari Lurah keluar, maka disepakati bersama ibu ketua TP-PKK Kelurahan Sungai Dama dan ditetapkan pelaksanaan kegiatan selama 4 hari yaitu tanggal 6-9 Februari tahun 2019. Tempat kegiatan dilangsungkan di ruang pertemuan Kelurahan Sungai Dama.

Pada hari pertama pelaksanaan kegiatan, pembukaan dihadiri Lurah, seluruh staf kelurahan dan para peserta pelatihan serta tim lengkap pengabdian masyarakat. Dalam sambutan pembukaannya Lurah menyampaikan terimakasih kepada UMKT yang telah memberikan program yang sangat bagus dan bermanfaat bagi meningkatkan perekonomian masyarakat kurang mampu dan berharap upaya yang dilakukan dapat berkembang sehingga sasaran dapat dicapai.

Hari kedua kegiatan dilanjutkan dengan praktik menggunting kain dengan menggunakan pola yang sudah dibuat, kemudian praktik melapis kain dengan vislin. Hari ketiga menjahit bagian bagian tas dan hari keempat praktik memasang kancing magnet dan restluiting, memasang tali tas dan menjahit tepi tas.

Hasil evaluasi pada hari ketiga sudah ada 3 orang kader yang mampu menyelesaikan pembuatan tas sedangkan yang 7 orang menyelesaikannya di hari ke 4 . Mulai hari pertama sampai hari terakhir peserta sangat antusias mengikuti pelatihan, bahkan mereka sudah merencanakan untuk membuat sendiri dan memodifikasi model yang sudah diberikan narasumber. Para kader juga merencanakan akan meneruskan pengetahuan dan skill yang mereka peroleh pada sanak keluarga dan tetangga, sehingga dengan bantuan Tim Penggerak PKK mereka akan merencanakan Kelurahan Sungai Dama menjadi kampung unggulan dibidang kerajinan.

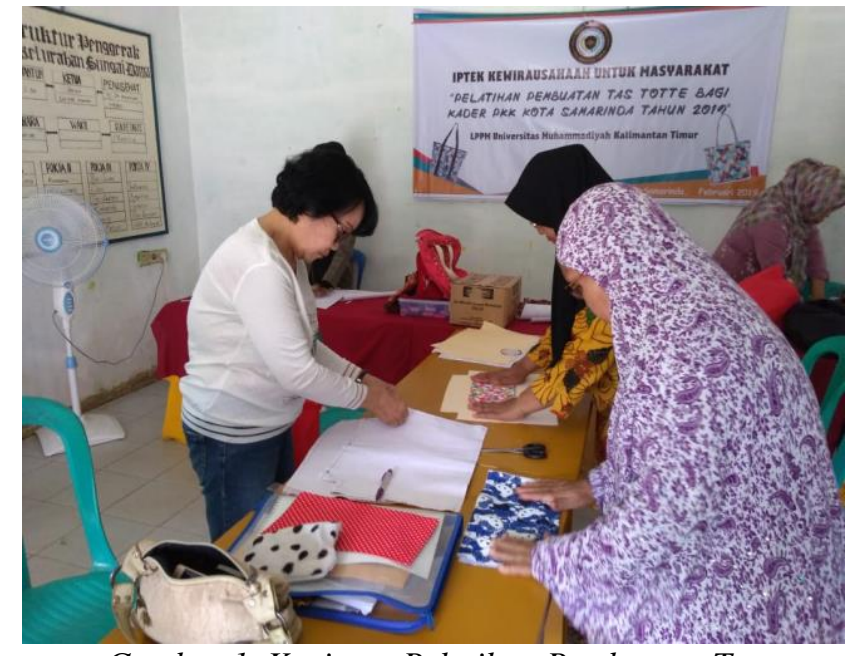

Gambar 1. Kegiatan Pelatihan Pembuatan Tas 


\section{(A) ABDIMAS}

https://journal.uwgm.ac.id/index.php/abdimasmahakam

E-ISSN: 2549-5755

Januari 2020, Vol. 4 No. 01

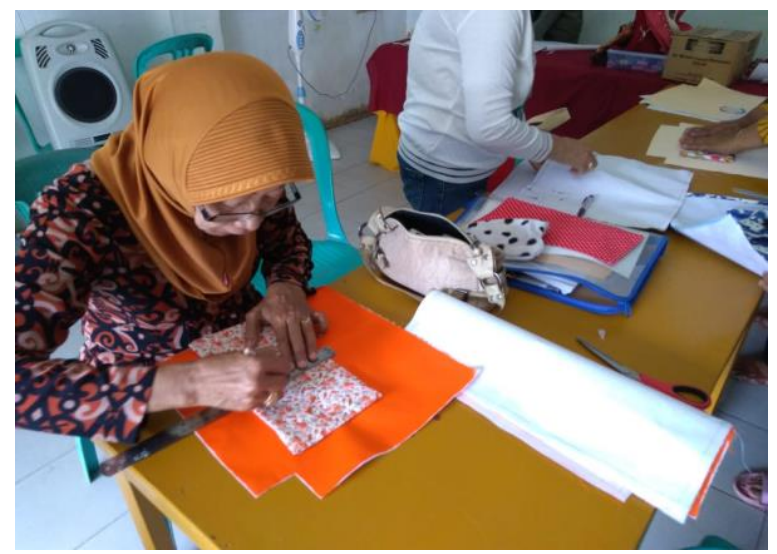

Gambar 2. Kegiatan Pelatihan Pembuatan Tas

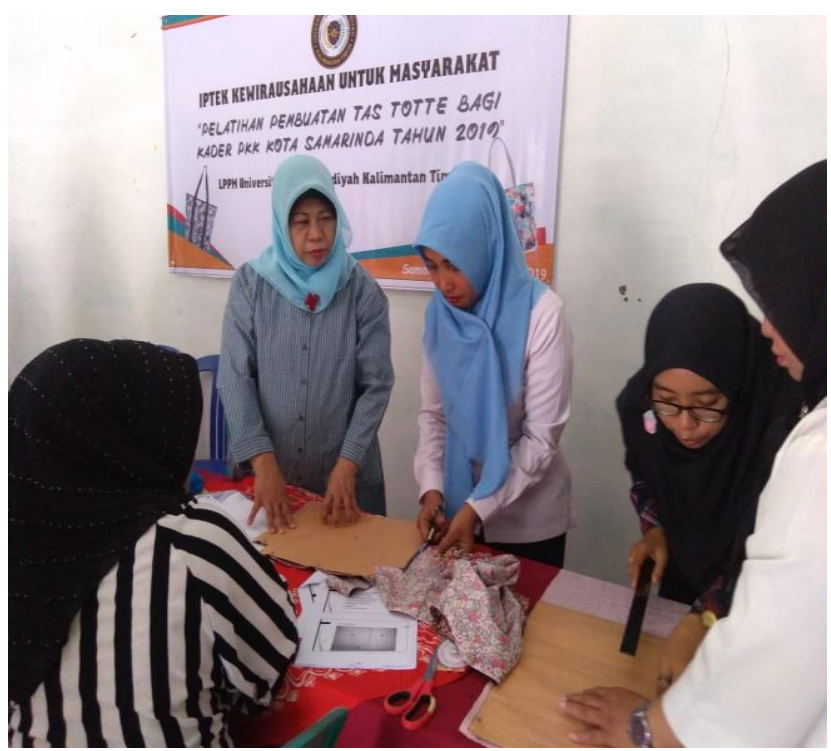

Gambar 3. Kegiatan Pelatihan Pembuatan Tas

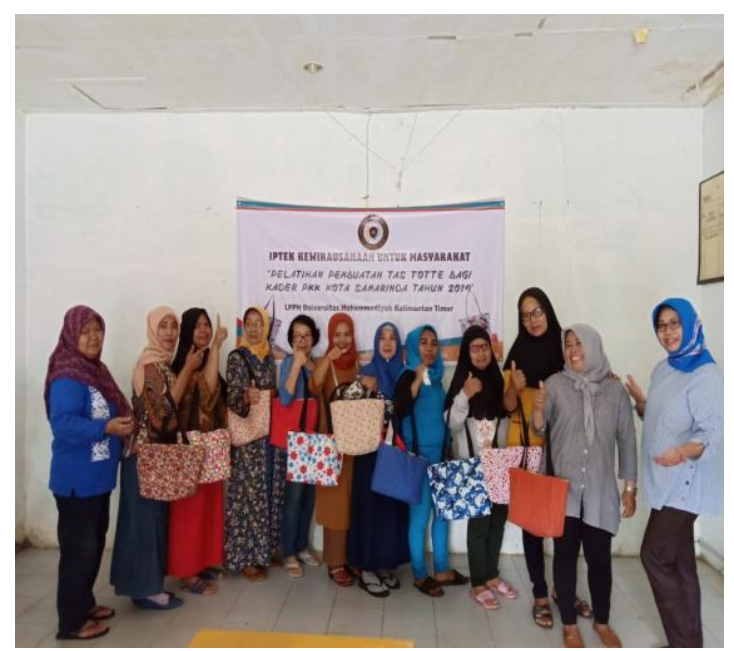

Gambar 4. Kegiatan Pelatihan Pembuatan Tas 


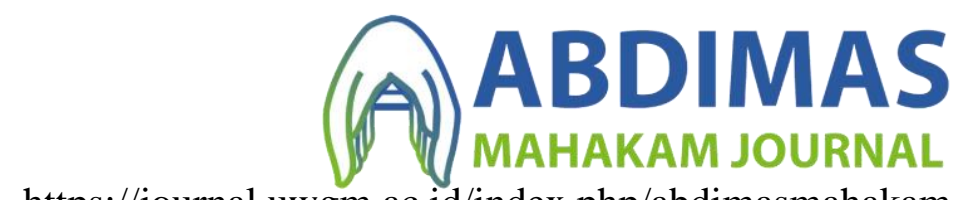

https://journal.uwgm.ac.id/index.php/abdimasmahakam

E-ISSN: 2549-5755

Januari 2020, Vol. 4 No. 01

\section{Simpulan dan rekomendasi}

Setelah dilakukan pelatihan semua peserta dapat membuat simple totte bag. Untuk kesempatan berikutnya akan diberikan lagi pengetahuan dalam mengembangkan keterampilan yang sudah didapat dengan menjalin kerjasama, Memorandum of Action (MoA) antara UMKT dengan Kelurahan Sungai Dama. 


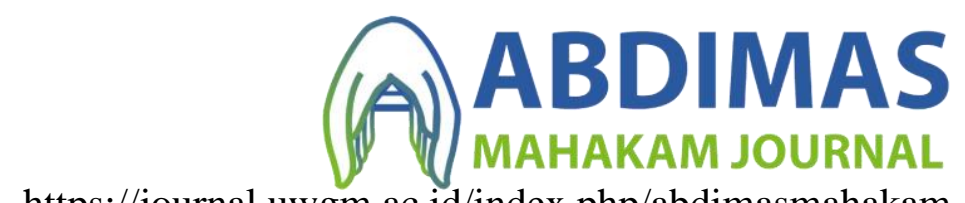

https://journal.uwgm.ac.id/index.php/abdimasmahakam

E-ISSN: 2549-5755

Januari 2020, Vol. 4 No. 01

\section{Daftar Pustaka}

Anonim, 2014, Berbagi makalah bertemakan kain bekas, Diunduh dari http://databermanfaat.blogspot.com/2018/06/berbagi makalah bertemakan kain perca

BPPM DIY, 2017, UsahaPeningkatan Pendapatan Keluarga,Yogyakarta

Rakernas PKK ke VIII tahun 2015, Buku Panduan Pemberdayaan Kesejahteraan Keluarga 